\title{
Polypyrimidine tract binding protein inhibits IgM pre-mRNA splicing by diverting U2 snRNA base-pairing away from the branch point
}

\author{
XUEXIU ZHENG, ${ }^{1}$ SUNGHEE CHO, ${ }^{1}$ HEEGYUM MOON, ${ }^{1}$ TIING JEN LOH, ${ }^{1}$ HUYN KYUNG OH, ${ }^{1}$ \\ MICHAEL R. GREEN, ${ }^{2}$ and HAIHONG SHEN ${ }^{1,3}$ \\ ${ }^{1}$ Department of Life Sciences, Gwangju Institute of Science and Technology, Gwangju 500-712, Korea \\ ${ }^{2}$ Howard Hughes Medical Institute and Programs in Gene Function and Expression and Molecular Medicine, University of Massachusetts Medical \\ School, Worcester, Massachusetts 01605, USA
}

\begin{abstract}
The mouse immunoglobulin (IgM) pre-mRNA contains a splicing inhibitor that bears multiple binding sites for the splicing repressor polypyrimidine tract binding protein (PTB). Here we show that the inhibitor directs assembly of an ATP-dependent complex that contains PTB and U1 and U2 small nuclear RNAs (snRNAs). Unexpectedly, although U2 snRNA is present in the inhibitor complex, it is not base-paired to the branch point. We present evidence that inhibitor-bound PTB contacts U2 snRNA to promote base-pairing to an adjacent branch point-like sequence within the inhibitor, thereby preventing the U2 snRNAbranch point interaction and resulting in splicing repression. Our studies reveal a novel mechanism by which PTB represses splicing.
\end{abstract}

Keywords: branch point; pre-mRNA splicing; polypyrimidine tract binding protein; PTB; splicing inhibitory complex; U2 snRNA

\section{INTRODUCTION}

Pre-mRNA splicing occurs in a ribonucleoprotein (RNP) complex called the spliceosome, which is composed of a large number of proteins and multiple $U$ small nuclear RNAs (snRNAs). U snRNAs promote splicing by participating in RNA-RNA and RNA-protein interactions. For example, base-pairing between the U2 snRNA and the branch point promotes the first catalytic step of the splicing reaction (for review, see Will and Luhrmann 2011; Hoskins and Moore 2012).

Pre-mRNA splicing can be negatively regulated by inhibitor sequences, which harbor binding sites for heterogeneous nuclear RNPs (hnRNPs) (for review, see Martinez-Contreras et al. 2007). The hnRNP polypyrimidine tract binding protein (PTB) (also called hnRNP I or PTBP1) is a $57-\mathrm{kDa}$ protein that binds to CU-rich sequences and represses splicing (for review, see Kafasla et al. 2012). Several mechanisms by which PTB can repress splicing have been reported. For example, in some pre-mRNAs, the PTB-binding site overlaps with the binding site for the essential splicing factor U2AF65,

\footnotetext{
${ }^{3}$ Corresponding author

E-mail haihongshen@gist.ac.kr

Article published online ahead of print. Article and publication date are at http://www.rnajournal.org/cgi/doi/10.1261/rna.043737.113.
}

and thus PTB blocks U2AF65 binding (Lin and Patton 1995; Singh et al. 1995; Wagner and Garcia-Blanco 2001; Sauliere et al. 2006). Recently, PTB has been found to directly contact $\mathrm{U} 1$ snRNA and is thought to prevent further assembly of U1 snRNA with downstream spliceosomal components (Sharma et al. 2011).

We have been studying PTB-mediated splicing repression using the mouse immunoglobulin (IgM) pre-mRNA. Splicing of IgM exons M1 and M2 is regulated by juxtaposed enhancer and inhibitor sequences located within exon M2 (Kan and Green 1999). In the absence of the enhancer, the inhibitor forms an ATP-dependent complex, called the inhibitor complex (complex I), which contains PTB (Kan and Green 1999; Shen et al. 2004a). Although PTB is required for inhibitor function, the mechanism by which PTB inhibits IgM pre-mRNA splicing remains unknown. Here we study how PTB represses IgM splicing by characterizing complex I with regard to U snRNA composition, PTB-U snRNA interactions, and U snRNA-inhibitor base-pairing.

\footnotetext{
(C) 2014 Zheng et al. This article is distributed exclusively by the RNA Society for the first 12 months after the full-issue publication date (see http://rnajournal.cshlp.org/site/misc/terms.xhtml). After 12 months, it is available under a Creative Commons License (Attribution-NonCommercial 3.0 Unported), as described at http://creativecommons.org/licenses/bync/3.0/.
} 


\section{RESULTS AND DISCUSSION}

\section{$\mathrm{U} 1$ and U2 snRNAs are present in, and are required for the formation of, complex I}

To study the basis of PTB-mediated splicing inhibition of the IgM pre-mRNA, we first determined the U snRNA composition of complex I. We have previously described a mouse IgM minigene containing exons M1 and M2 (IgM1-2), and a derivative in which the enhancer in exon M2 has been deleted (IgM $\triangle$ E) (Fig. 1A; Kan and Green 1999; Shen and Green 2004; Shen et al. 2004a). Following incubation of the premRNAs in nuclear extract, splicing complexes were fractionated on native polyacrylamide gels (Fig. 1B). RNAs were eluted from the nonspecific $(\mathrm{H})$, prespliceosome $(\mathrm{A})$, mature spliceosome $(\mathrm{B} / \mathrm{C})$, and I complexes, and U sRNAs present in each complex were then detected by Northern blotting. The results of Figure 1C show that complex I contained U1 and U2 snRNAs.

To determine whether U1 and U2 snRNAs were required for formation of complex I, we analyzed complex I formation in nuclear extracts following oligonucleotide-directed RNase
$\mathrm{H}$ cleavage of U1 or U2 snRNA. The results in Figure 1D show that U1 or U2 snRNA-depleted nuclear extract failed to support formation of complex I.

\section{PTB contacts U2 snRNA in complex I}

We next asked whether PTB contacts U snRNAs. In the first set of experiments, we assembled splicing reaction mixtures that contained the IgM $\Delta \mathrm{E}$ or IgM1-2 pre-mRNA substrate or, as a control, no pre-mRNA. Following incubation, the reaction mixtures were irradiated with ultraviolet (UV) light to induce RNA-protein crosslinks and immunoprecipitated with an anti-PTB antibody, and the immunoprecipitates were analyzed for $\mathrm{U}$ snRNAs by primer-extension analysis. Figure 1E shows, consistent with previous results (Sharma et al. 2011), that PTB contacted U1 snRNA in the presence or absence of a pre-mRNA substrate. Also consistent with previous results, the PTB-U1 snRNA interaction was not ATP dependent.

Notably, an association between PTB and U2 snRNA was also detected but only occurred with the $\operatorname{IgM} \Delta \mathrm{E}$ pre-

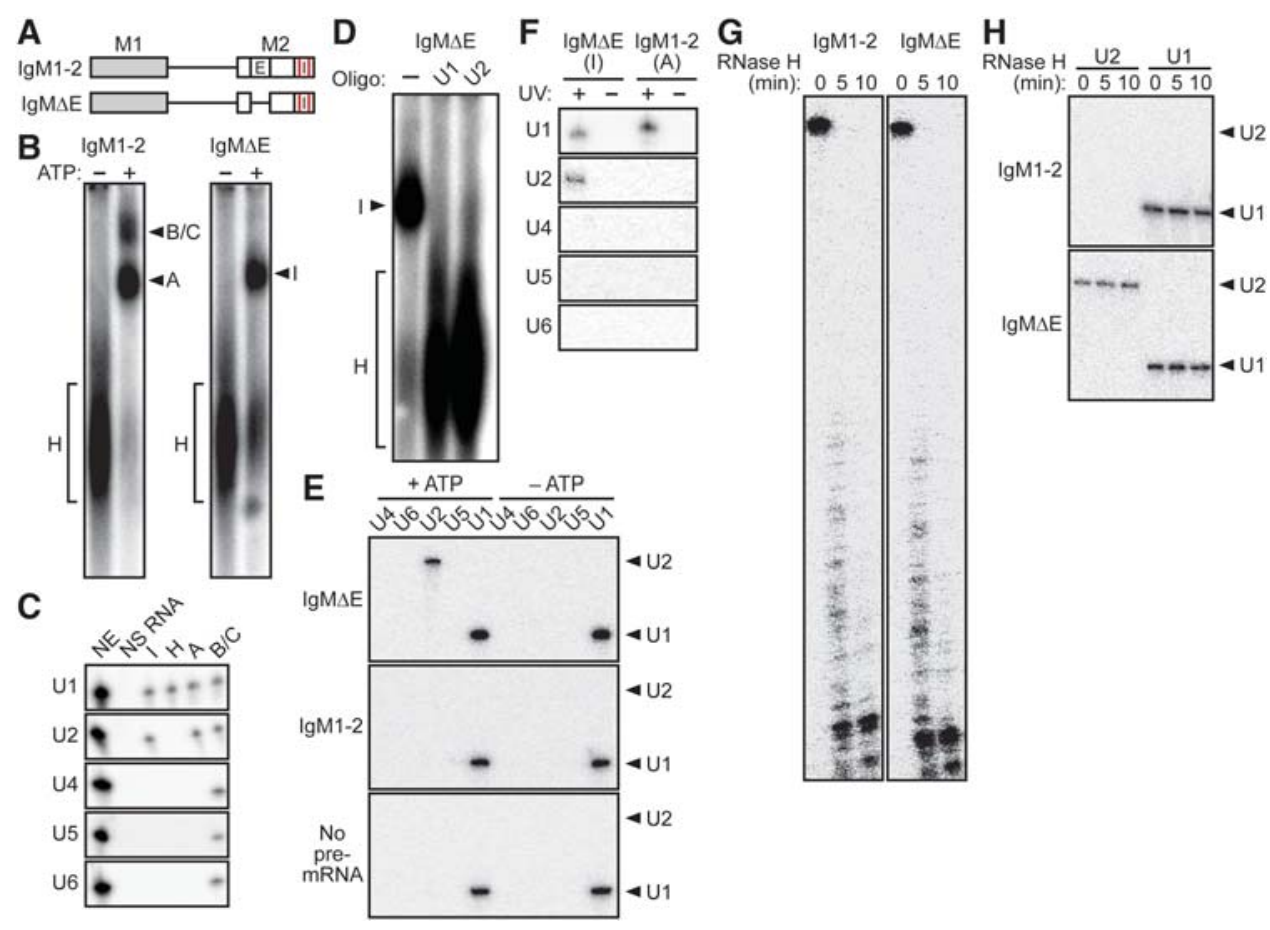

FIGURE 1. PTB directly contacts U2 snRNA in complex I. (A) Schematic diagrams of the IgM1-2 pre-mRNA substrate and deletion derivative lacking the enhancer (IgM $\Delta \mathrm{E})$. M1 and M2 indicate exons M1 and M2, respectively; E, enhancer; and I, inhibitor. The red vertical lines in the inhibitor represent the two PTB-binding sites. (B) Native polyacrylamide gels showing fractionation of splicing complexes on IgM1-2 and IgM $\Delta \mathrm{E}$ pre-mRNAs. $(C)$ Northern blotting analysis of U1, U2, U4, U5, and U6 snRNAs in RNA eluted from complex I (formed on the IgM $\triangle \mathrm{E}$ pre-mRNA) and from complexes $\mathrm{H}, \mathrm{A}$, and $\mathrm{B} / \mathrm{C}$ (formed on the IgM1-2 pre-mRNA). NE indicates nuclear extract; NS RNA, nonspecific RNA. (D) Complex I formation on IgM $\Delta \mathrm{E}$ following RNase $\mathrm{H}$-directed cleavage of U1 or U2 shRNA. (E) Primer extension analysis monitoring the presence of U snRNAs in the antiPTB immunoprecipitate from UV-irradiated splicing reactions containing IgM $\triangle \mathrm{E}$, IgM1-2, or no pre-mRNA, in the presence or absence of ATP. The positions of U1 and U2 shRNAs are indicated. $(F)$ Northern blotting analysis of U snRNAs in anti-PTB immunoprecipitates from purified complex I or A eluted from a native polyacrylamide gel after UV irradiation. $(G)$ Oligonucleotide-directed RNase $\mathrm{H}$ degradation of IgM1-2 and IgM $\Delta \mathrm{E}$ premRNA substrates. $(H)$ Primer extension analysis monitoring the presence of U1 or U2 snRNA in the anti-PTB immunoprecipitate from UV-irradiated splicing reactions following RNase H-mediated degradation of IgM1-2 or IgM $\Delta$ E pre-mRNA. 
mRNA substrate and in the presence of ATP, reminiscent of the requirement for complex I formation (Kan and Green 1999). We therefore hypothesized that PTB contacted U2 snRNA specifically in complex I. To test this possibility, we purified complex I-and, as a control, complex A—on a native polyacrylamide gel and, after UV crosslinking, eluted the protein-RNA complex, immunoprecipitated with an antiPTB antibody, and analyzed for the presence of U1 and U2 snRNAs by Northern blot analysis. The results in Figure 1F show that U2 snRNA was present in the PTB immunoprecipitate of complex I. Consistent with previous results (Sharma et al. 2011) and those shown in Figure 1E, PTB also contacted U1 snRNA in complexes I and A.

In the experiments described above, it remained possible that the association between PTB and U2 snRNA was not direct but rather occurred indirectly as a result of PTB and U2 snRNP contacting, and being crosslinked to, separate regions of the pre-mRNA. The intervening pre-mRNA region would then serve as a tether such that U2 snRNA would be coimmunoprecipitated with PTB. To rule out this possibility, following UV crosslinking we extensively degraded the premRNA. In brief, we assembled splicing reaction mixtures that contained either the IgM1-2 or IgM $\Delta$ E pre-mRNA substrate, and, following UV crosslinking, we performed oligonucleotide-directed RNase $\mathrm{H}$ degradation of the pre-mRNA substrates. The results of Figure $1 \mathrm{G}$ confirmed extensive degradation of the IgM1-2 and IgM $\Delta \mathrm{E}$ pre-mRNAs.

Following immunoprecipitation with an anti-PTB antibody, we then monitored for the presence of $U$ snRNAs by primer extension analysis. The results of Figure $1 \mathrm{H}$ show, as expected, that with the IgM1-2 pre-mRNA substrate, U1 snRNA but not U2 snRNA was present in the PTB immunoprecipitate. Notably, with the $\operatorname{IgM} \Delta \mathrm{E}$ premRNA substrate, both U1 and U2 snRNAs were present in the PTB immunoprecipitate. These results provide further evidence that PTB contacts U2 snRNA on the IgM $\Delta \mathrm{E}$ premRNA substrate.

\section{U2 snRNA is not base-paired with the branch point in complex $I$}

To further study the basis of PTB-mediated splicing inhibition, we characterized U2 snRNA base-pairing interactions in complex I. As stated above, in the prespliceosome, U2 snRNA base-pairs with the branch point. We therefore first analyzed base-pairing between U2 snRNA and the branch point using a UV RNA-RNA crosslinking assay. IgM1-2 or IgM $\triangle \mathrm{E}$ pre-mRNA was uniformly labeled with ${ }^{32} \mathrm{P}$ and site-specifically labeled at the branch point with 4-thiouridine to facilitate RNA-RNA crosslinking (Wyatt et al. 1992). Following incubation in nuclear extract and UV crosslinking, the RNA products were fractionated on a denaturing polyacrylamide gel and detected by autoradiography.

Figure 2A shows that on the IgM1-2 pre-mRNA substrate and in the presence of ATP there was a UV-dependent band

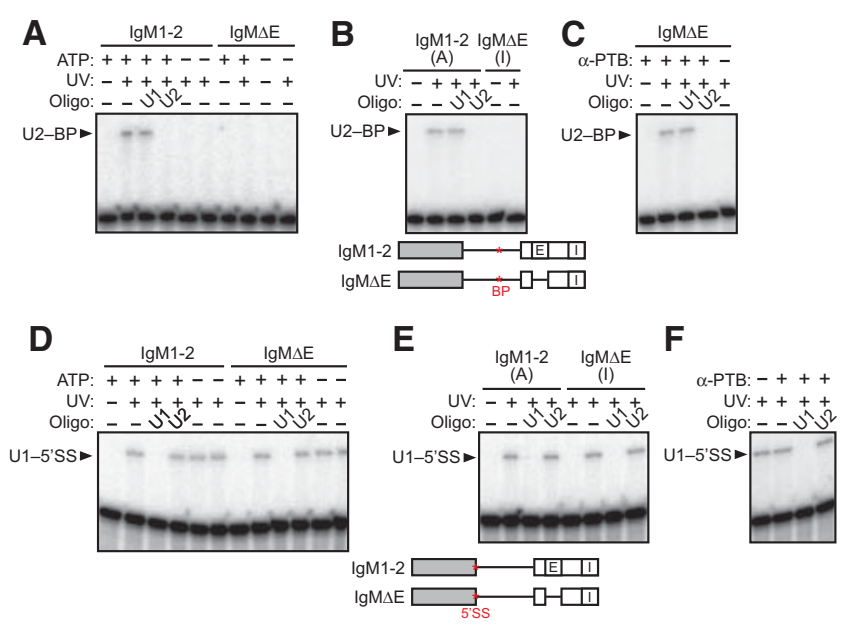

FIGURE 2. U2 snRNA is not base-paired with the branch point in complex I. (A) UV RNA-RNA crosslinking analysis using a uniformly ${ }^{32} \mathrm{P}$-labeled IgM $\triangle \mathrm{E}$ or, as a control, IgM1-2 pre-mRNA site-specifically labeled with 4-thiouridine at the branch point (indicated by the red asterisk). Reactions were performed in the presence or absence of ATP, $\mathrm{UV}$, or RNase $\mathrm{H}$-directed cleavage of U1 or U2 snRNA. The position of the U2 snRNA-branch point (U2-BP) crosslinked product is shown. (B) UV RNA-RNA crosslinking analysis performed on purified complex A (from IgM1-2) or I (from IgM $\Delta \mathrm{E}$ ) in the presence or absence of UV or RNase H-directed cleavage of U1 or U2 snRNA. (C) UV RNA-RNA crosslinking analysis using $\operatorname{IgM} \Delta \mathrm{E}$ in the presence or absence of a PTB antibody, UV, or RNase H-directed cleavage of U1 or U2 snRNA. ( $D-F)$ UV RNA-RNA crosslinking analysis as described in $A$ through $C$, except the pre-mRNAs were site-specifically labeled with 4 -thiouridine at the $5^{\prime}$ splice site (indicated by the red asterisk). The position of the U1 snRNA-5' splice site (U1-5'SS) crosslinked product is shown.

with altered electrophoretic mobility (arrowhead), indicative of an RNA-RNA crosslink. The RNA-RNA crosslink was not detectable after $\mathrm{U} 2$ snRNA oligonucleotide-directed RNase $\mathrm{H}$ treatment. Therefore on the IgM1-2 pre-mRNA, the RNARNA crosslink corresponds to the expected base-pairing interaction between U2 snRNA and the pre-mRNA branch point. In contrast, in a comparable crosslinking experiment using the IgM $\triangle \mathrm{E}$ pre-mRNA, a base-pairing interaction between U2 snRNA and the branch point was not detected. Thus, on the IgM $\Delta \mathrm{E}$ pre-mRNA, U2 snRNA is not basepaired with the branch point.

To confirm these results, we also performed UV RNARNA crosslinking on purified complexes A and I isolated by fractionation on a native polyacrylamide gel. The results of Figure 2B confirm that U2 snRNA was base-paired to the branch point in complex A but not complex I.

We have previously shown that addition of an anti-PTB antibody antagonizes the inhibitor, enabling splicing of the $\operatorname{IgM} \Delta \mathrm{E}$ pre-mRNA to occur (Shen et al. 2004a). Figure 2C shows that addition of the anti-PTB antibody enabled formation of the U2 snRNA-branch point interaction on the $\operatorname{IgM} \Delta \mathrm{E}$ pre-mRNA substrate. Collectively, these results indicate that in complex I, PTB prevents formation of the U2 snRNA-branch point interaction. 
As a specificity control, we performed a comparable set of experiments with IgM1-2 and IgM $\Delta \mathrm{E}$ pre-mRNAs that were uniformly labeled with ${ }^{32} \mathrm{P}$ and site-specifically labeled at the $5^{\prime}$ splice site with 4-thiouridine. The results show, as expected, that the $5^{\prime}$ splice site was base-paired with U1 snRNA in both IgM1-2 and IgM $\Delta$ E pre-mRNAs in the presence or absence of ATP (Fig. 2D) in both complexes A and I (Fig. 2E). Furthermore, addition of the anti-PTB antibody did not affect the base-pairing between U1 snRNA and the $5^{\prime}$ splice site (Fig. 2F).

\section{PTB promotes base-pairing between U2 snRNA and the inhibitor}

The results described above raised the possibility that in complex I, U2 snRNA is base-paired with a region of the premRNA other than the branch point. Because PTB contacts both U2 snRNA and the inhibitor region simultaneously, we investigated whether U2 snRNA is base-paired with the inhibitor region. We first performed UV crosslinking analysis on IgM $\Delta \mathrm{E}$ and IgM1-2 pre-mRNA substrates that were uniformly labeled with ${ }^{32} \mathrm{P}$ and site-specifically labeled with 4 thiouridine at the inhibitor region. The results of Figure $3 \mathrm{~A}$ show that with IgM $\triangle \mathrm{E}$ in the presence of ATP there was
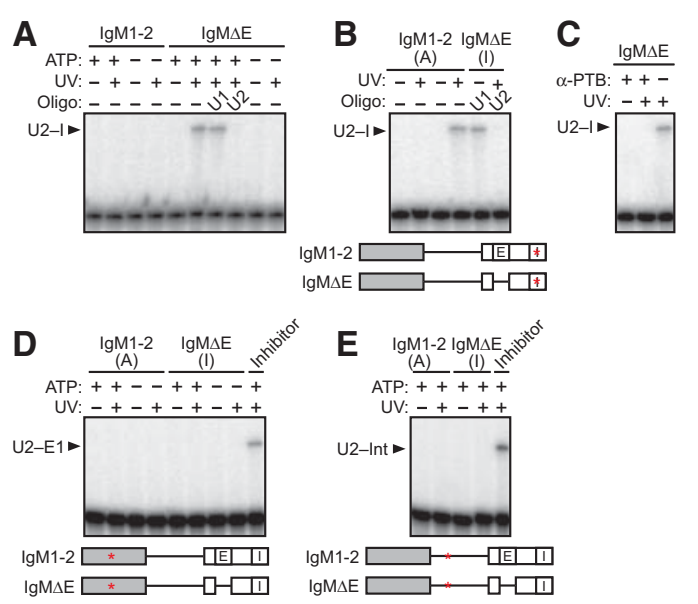

FIGURE 3. PTB promotes base-pairing between U2 snRNA and the inhibitor. (A) UV RNA-RNA crosslinking analysis using a uniformly ${ }^{32} \mathrm{P}$-labeled IgM $\Delta \mathrm{E}$ or, as a control, IgM1-2 pre-mRNA site-specifically labeled with 4-thiouridine in the inhibitor region (indicated by the red asterisk). Reactions were performed in the presence or absence of ATP, $\mathrm{UV}$, or RNase H-directed cleavage of U1 or U2 snRNA. The position of the U2 snRNA-inhibitor (U2-I) crosslinked product is shown. (B) UV RNA-RNA crosslinking analysis performed on purified complex A (from IgM1-2) or I (from IgM $\Delta \mathrm{E}$ ) in the presence or absence of $\mathrm{UV}$ or RNase $\mathrm{H}$-directed cleavage of U1 or U2 snRNA. (C) UV RNA-RNA crosslinking analysis using IgM $\Delta \mathrm{E}$ in the presence or absence of a PTB antibody, UV, or RNase H-directed cleavage of U1 or U2 snRNA. ( $D, E)$ UV RNA-RNA crosslinking analysis as described in $A$, except the pre-mRNAs were site-specifically labeled with 4-thiouridine in exon $1(D)$ or the intron $(E)$ (indicated by the red asterisk). The positions of the U2 snRNA-exon 1 (U2-E1) and U2 snRNA-intron (U2-Int) crosslinked products are shown. a UV-dependent band with altered electrophoretic mobility, indicative of an RNA-RNA crosslink. Oligonucleotidedirected RNase $\mathrm{H}$ cleavage demonstrated that the RNA-RNA crosslink contained U2 snRNA. In contrast, the IgM1-2 pre-mRNA substrate did not support formation of this RNA-RNA crosslink. We conclude that on the IgM $\Delta \mathrm{E}$ premRNA substrate, U2 snRNA is base-paired with the inhibitor.

To confirm these results, we also performed UV crosslinking analysis on complexes A and I following isolation on a native polyacrylamide gel. The results of Figure $3 \mathrm{~B}$ show that U2 snRNA was base-paired with the inhibitor in complex I but not complex A. Furthermore, the UV crosslinking analysis of Figure 3C shows that addition of the anti-PTB antibody resulted in loss of the U2 snRNA-inhibitor interaction. Thus, PTB is required for base-pairing between U2 snRNA and the inhibitor in complex I.

To provide additional evidence for the specificity of the U2 snRNA-inhibitor interaction, we prepared IgM $\Delta \mathrm{E}$ and IgM1-2 pre-mRNA substrates that were uniformly labeled with ${ }^{32} \mathrm{P}$ and site-specifically labeled with 4 -thiouridine at exon 1 or an irrelevant intronic region. The results of Figure 3, D and E, show that U2 snRNA did not bind to either exon 1 or the intron.

\section{Delineating the elements required for the U2 snRNA-inhibitor interaction}

To further delineate the region of the IgM inhibitor that basepairs with U2 snRNA, we performed UV crosslinking experiments. We have previously shown that the IgM inhibitor harbors two sets of PTB-binding sites, referred to as PTB sites I and II, of which only site I is required for inhibitor activity (Shen et al. 2004a). To sample the entire inhibitor region, we constructed a series of $\operatorname{IgM} \Delta \mathrm{E}$ derivatives that contained 4thiouridine inserted at seven different positions located either within or outside of the two PTB-binding sites (Fig. 4A, bottom). The results of Figure 4A show that only two IgM 4thiouridine derivatives, IgM-4TU3 and IgM-4TU4, both containing 4-thiouridine substitutions within site I, enabled formation of a U2 snRNA-inhibitor crosslink. Thus, the U2 snRNA-inhibitor base-pairing interaction occurs at site I.

We noticed that within site I there was a potential U2 snRNA base-pairing sequence that overlapped with the two PTB-binding consensus motifs (UCUU) (Fig. 4A, bottom; Perez et al. 1997). To determine the function of each of these elements, we constructed a series of $\operatorname{IgM} \Delta \mathrm{E}$ derivatives, sitespecifically labeled with 4-thiouridine within PTB site I, containing mutations that disrupted either of the two PTB-binding consensus motifs or the potential U2 snRNA base-pairing region. The results of Figure $4 \mathrm{~B}$ show that none of these three mutants supported the U2 snRNA-inhibitor base-pairing interaction. We conclude that the unusual configuration of two PTB consensus motifs surrounding a U2 snRNA basepairing region is required for $\mathrm{PTB}$ to promote the U2 


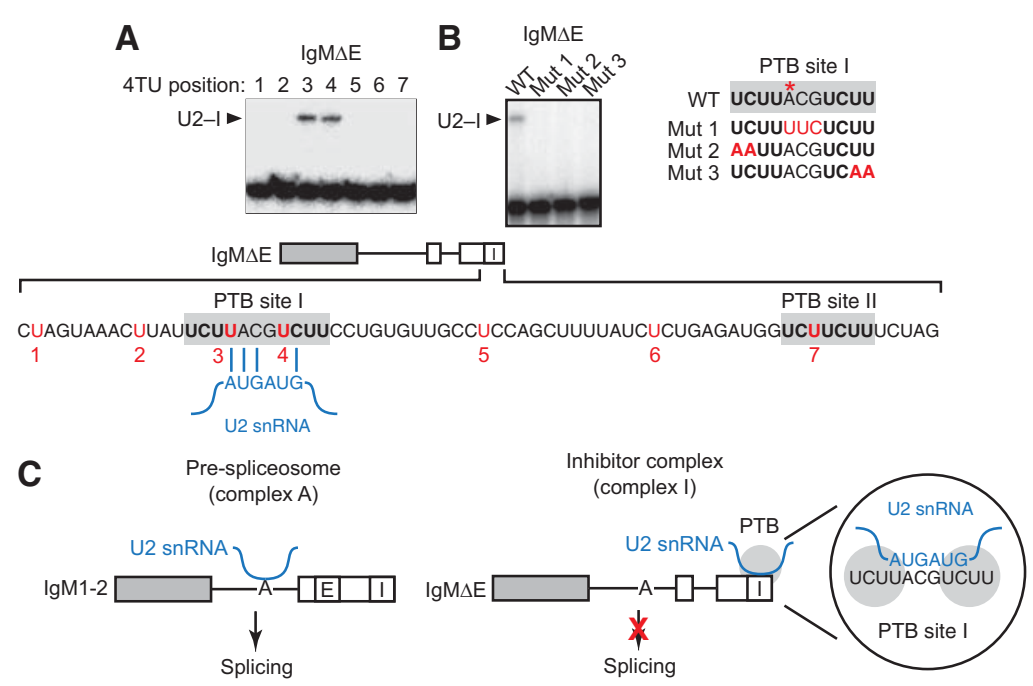

FIGURE 4. Delineating the elements required for the U2 snRNA-inhibitor interaction. (A) UV RNA-RNA crosslinking analysis on a series of $\operatorname{IgM} \Delta \mathrm{E}$ derivatives containing 4-thiouridine (4TU) inserted at seven different positions within the inhibitor region (shown on the bottom). The position of the U2 snRNA-inhibitor (U2-I) crosslinked product is shown. (B) UV RNA-RNA crosslinking analysis on IgM $\triangle \mathrm{E}$ derivatives in which PTB site I was mutated in the putative U2 snRNA binding site and one of the PTB-binding consensus motifs (shown on the right). All substrates were site-specifically labeled with 4 -thiouridine at the position indicated by the red asterisk. (C) Model for PTB-mediated inhibition of IgM pre-mRNA splicing.

snRNA-inhibitor interaction and to repress splicing. The results of Figure 4, A and B, further suggest that the branch point-binding site (GUAGUA) is the U2 snRNA region that interacts with the inhibitor.

Several diverse mechanisms have been described to explain how PTB inhibits splicing. For example, in pre-mRNAs in which the polypyrimidine tract contains a high-affinity PTBbinding site, PTB can inhibit splicing by competing for binding with the essential splicing factor U2AF (Lin and Patton 1995; Singh et al. 1995; Wagner and Garcia-Blanco 2001; Sauliere et al. 2006). However, because PTB-binding sites are often located between the branch point and $5^{\prime}$ splice site, PTB must be able to inhibit splicing by more complex mechanisms than simply blocking early spliceosomal factors. Consistent with this idea, the splice sites of some repressed exons can still assemble the initial spliceosomal components U1 snRNP and U2AF but cannot undergo later steps of assembly (Izquierdo et al. 2005; Sharma et al. 2005, 2008). An alternative model has postulated that PTB binding to a high-affinity site nucleates its oligomerization along the RNA to prevent recognition of splice sites (Wagner and Garcia-Blanco 2001). Finally, another model posits that distant PTB molecules interact and loop out splicing signals, thereby inhibiting spliceosome assembly (Chou et al. 2000).

In this report, we have described a new mechanism by which PTB can inhibit splicing on the IgM pre-mRNA, which is summarized in Figure $4 \mathrm{C}$ and discussed below. We find that the IgM splicing inhibitor is assembled into an ATPdependent complex whose formation requires PTB and U2 snRNP. In this complex I, PTB contacts U2 snRNA and in- duces base-pairing to a branch pointlike sequence adjacent to the PTB-binding site. The U2 snRNA-inhibitor basepairing interaction prevents U2 snRNA base-pairing with the authentic branch point and thus splicing does not occur. According to this model, the proximity of the inhibitor to the authentic branch point may be critical to obtain splicing repression. The interaction of $\mathrm{U} 2 \mathrm{snRNA}$ with RNA-bound PTB could provide the basis for the preferential recruitment of U2 snRNP to the inhibitor and not to the authentic branch point. In this regard, it will be important to conclusively demonstrate that PTB interacts directly with U2 snRNA, which will require delineation of the U2 snRNA region contacted by PTB. Interestingly, the drug spliceostatin A, a splicing inhibitor, induces a loss of branch point fidelity, resulting in U2 snRNP binding to nonproductive decoy branch point-like sequences (Corrionero et al. 2011), which is reminiscent of the splicing repression mechanism described here.

As mentioned above, the IgM enhancer can counteract the inhibitor, enabling splicing to occur. The detailed mechanism by which the IgM enhancer functions remains to be determined. However, an attractive idea is that the enhancer promotes binding of U2 snRNP to the authentic branch point, thereby outcompeting the inhibitor.

The possibility that PTB contacts spliceosomal components is consistent with a previous study showing that PTB contacts U1 snRNA (Sharma et al. 2011). We also find that PTB contacts U1 snRNA. However, whereas the PTB-U1 snRNA contact is ATP-independent, the PTB-U2 snRNA contact requires ATP. Binding of PTB to U2 snRNA is unlikely to be ATP dependent, and thus the mechanistic basis of the ATP requirement for the PTB-U2 snRNA interaction and complex I formation is currently unknown. Notably, similar to our results, an exonic splicing silencer that represses splicing of PTPRC (encoding CD45) forms an ATP-dependent complex that contains U1 and U2 snRNPs (House and Lynch 2006).

\section{MATERIALS AND METHODS}

\section{Generation of pre-mRNA substrates}

The IgM1-2 and IgM $\Delta \mathrm{E}$ pre-mRNA substrates were transcribed from plasmids $\mathrm{p} \mu \mathrm{M} 1-2$ and $\mathrm{p} \mu \mathrm{M} \Delta \mathrm{E}$ (Watakabe et al. 1993). PTB site I mutants were constructed in $\mathrm{p} \mu \mathrm{M} \Delta \mathrm{E}$ using a PCR-based strategy. The nonspecific RNA control was generated by T7 transcription from NdeI-linearized pSP72 (Promega). 


\section{Spliceosome assembly reactions}

Spliceosome assembly reactions were performed essentially as described previously (Kan and Green 1999) using IgM1-2 and $\operatorname{IgM} \Delta \mathrm{E}$ pre-mRNA substrates. Briefly, spliceosomal complexes $\mathrm{H}$, $\mathrm{A}, \mathrm{B}, \mathrm{C}$, and I were resolved on nondenaturing $4 \%$ acrylamide:bisacrylamide (80:1)/0.5\% low-melting agarose in $50 \mathrm{mM}$ Tris base/50 $\mathrm{mM}$ glycine buffer (Wu and Green 1997). ${ }^{32} \mathrm{P}$-labeled signals were visualized by PhosphorImager (Fujifilm FLA-7000 imaging system). Inactivation of U1 or U2 snRNA in nuclear extracts by oligonucleotide-directed RNase $\mathrm{H}$ cleavage was performed as described previously (Shen et al. 2004b) using a DNA oligonucleotide complementary to the $5^{\prime}$ end of the U1 snRNA or to the branch point basepairing region in the $\mathrm{U} 2$ snRNA.

\section{Northern blot analysis}

Northern blot analysis was performed as previously described (Kan and Green 1999). Briefly, after separating the splicing complexes on native gels, the RNA-protein complexes were eluted from the native gel and treated with protease A. Purified RNAs were electrophoresed on a $5 \%$ denaturing polyacrylamide gel and transferred to a membrane by electroblotting in $0.5 \times$ TBE buffer for $30 \mathrm{~min}$ at $60 \mathrm{~mA}$. The membrane was probed with a ${ }^{32} \mathrm{P}$-end-labeled anti-U1, -U2, -U4, -U5, or -U6 snRNA oligonucleotide.

\section{UV crosslinking/immunoprecipitation assays}

UV crosslinking was performed essentially as described (Shen et al. 2008). In brief, spliceosome assembly reactions were performed as described above in a total volume of $60 \mu \mathrm{L}$. The reaction mixture was irradiated with UV light $(254 \mathrm{~nm})$ for a total of $1.2 \mathrm{~J}$ using a Stratagene UV crosslinker. For immunoprecipitation, UV crosslinked reaction mixtures were incubated with $8 \mu \mathrm{L}$ of an anti-PTB antibody (BB7; kindly provided by Douglas Black) for $2 \mathrm{~h}$ at $4^{\circ} \mathrm{C}$. Anti-mouse IgG agarose beads ( $15 \mu \mathrm{L}$ bead volume) were added, and the reaction mixture was then incubated for an additional 2-3 $\mathrm{h}$ with continuous mixing on a rotator at $4^{\circ} \mathrm{C}$. Total RNA was purified from the immunoprecipitate using RiboEx reagent (GeneAll) according to the manufacturer's instructions, and $1 \mu \mathrm{g}$ was used in a primer extension reaction containing ImProm-II reverse transcriptase (Promega), dNTP mix, and ${ }^{32} \mathrm{P}$-labeled oligonucleotides specific for U1, U2, U4, U5, or U6 snRNA. Primers used for extension were complementary to nucleotides $64-86$ of human U1 snRNA, 100-122 of U2 snRNA, 65-85 of U4 snRNA, 55-75 of U5 snRNA, and 33-58 of U6 snRNA. For reactions done in the absence of ATP, the nuclear extract was preincubated for $30 \mathrm{~min}$ at $30^{\circ} \mathrm{C}$.

For Figure 1F, spliceosomal complexes were resolved as described above. The gels were UV irradiated on ice using a Stratagene UV crosslinker at $2 \mathrm{~J} / \mathrm{cm}^{2}$ (Wu and Green 1997). After UV crosslinking, gel slices containing complexes from a 30-min splicing reaction were excised and eluted with Quik-Pik electroelution capsules (Stratagene) in TBE buffer for $2 \mathrm{~h}$ at $4^{\circ} \mathrm{C}$. The eluted solution was immunoprecipitated with an anti-PTB antibody as previously described (Markovtsov et al. 2000) and analyzed for U shRNAs by Northern blotting.

To prepare the single-stranded DNA for oligonucleotide-directed RNase $\mathrm{H}$ digestion in Figure $1 \mathrm{G}$, IgM pre-mRNA was reverse transcribed, and the reaction mixture was digested with RNA, phenol extracted and ethanol precipitated to remove template RNA. The DNA was then further purified on an acrylamide gel. Following UV-crosslinking of the splicing reaction mixtures containing uniformly ${ }^{32} \mathrm{P}$-labeled pre-mRNA, the purified single-stranded DNA and $\mathrm{RNase} \mathrm{H}$ were added, and the reaction mixture was incubated for 5 or $10 \mathrm{~min}$ at $37^{\circ} \mathrm{C}$. Pre-mRNA degradation was monitored by polyacrylamide gel electrophoresis. For Figure $1 \mathrm{H}$, following UV irradiation of the splicing reaction mixture, PTB was immunoprecipitated. A single-stranded DNA oligonucleotide complementary to the inhibitor sequence was added, and RNase $\mathrm{H}$ digestion was performed. Primer extension analysis was performed to detect $\mathrm{U}$ snRNAs.

\section{UV RNA-RNA crosslinking assays}

UV crosslinking reactions were carried out in $40 \%$ nuclear extract, under conditions that promote splicing as described previously (Shen et al. 2008), in the presence of an IgM1-2 or IgM $\Delta \mathrm{E}$ premRNA that was universally labeled with ${ }^{32} \mathrm{P}$ and site-specifically labeled with 4 -thiouridine. Labeled pre-mRNA substrates were synthesized in three fragments. The first and third fragments, designed to encompass the region upstream of and downstream from, respectively, the 4-thiouridine label, were universally labeled with ${ }^{32} \mathrm{P}-\mathrm{CTP}$. The second fragment $(15-20 \mathrm{nt})$ was universally ${ }^{32} \mathrm{P}$-labeled and site-specifically labeled with 4-thiouridine using T7 RNA polymerase in a stepwise walking method (Shen and Kang 2001). Substrates were 4-thiouridine-labeled at the following positions (indicated by underlining): branch point (GCAAUU CACA, where the bolded A indicates the branch point); 5 ' splice site (exactly at the $5^{\prime}$-G $\underline{U}$ ); inhibitor (PTB I site, UCUUACGUC $\mathrm{UU}$ ); exon 1 (49 nucleotides upstream of the $5^{\prime}$ splice site, GUCC $\mathrm{U}$ ); and intron (33 nucleotides downstream from the $5^{\prime}$ splice site, GCUGG). The second and third fragments were then treated with alkaline phosphatase for $30 \mathrm{~min}$ at $37^{\circ} \mathrm{C}$, followed by $5^{\prime}$ end phosphorylation with ATP and polynucleotide kinase. The three fragments were annealed to bridging DNA oligonucleotides and ligated using T4 DNA ligase. The ligation product was purified following electrophoresis on an $8 \%$ denaturing polyacrylamide gel.

At $20 \mathrm{~min}$ following the start of the splicing reaction, the reaction mixture was UV-irradiated ( $302 \mathrm{~nm}$ ) for $10 \mathrm{~min}$ on ice to generate RNA-RNA cross-links and deproteinized with proteinase $\mathrm{K}$ treatment, followed by phenol-chloroform (1:1) extraction and ethanol precipitation to isolate RNA. To identify the snRNA involved in potential RNA-RNA cross-links, isolated RNA was analyzed on a $4 \%$ denaturing polyacrylamide and detected by PhosphorImager (Fujifilm FLA-7000 imaging system). For Figure 2B, the native gel was UV-irradiated $(302 \mathrm{~nm})$. Total RNA was then extracted from the native gel. For Figure 2, C and F, splicing mixtures in the absence of pre-mRNA were incubated with anti-PTB antibody for $5 \mathrm{~min}$ at $30^{\circ} \mathrm{C}$ and then pre-mRNA was added.

\section{ACKNOWLEDGMENTS}

We thank Douglas Black for providing reagents and Sara Deibler for editorial assistance. This work was supported by National Research Foundation (NRF) grants NRF-2011-0016757 and NRF-2013R 1A1A2062582 to H.S. and NRF-2013R1A1A2061321 to X.Z., which were funded by the Ministry of Education, Science, and Technology (MEST), Republic of Korea; a Systems Biology Infrastructure 
Establishment grant provided by Gwangju Institute of Science and Technology GIST in 2013; and a grant from the National Institutes of Health (R01GM035490) to M.R.G., who is also an investigator of the Howard Hughes Medical Institute.

Received December 2, 2013; accepted January 27, 2014.

\section{REFERENCES}

Chou MY, Underwood JG, Nikolic J, Luu MH, Black DL. 2000. Multisite RNA binding and release of polypyrimidine tract binding protein during the regulation of $c$-src neural-specific splicing. Mol Cell 5: 949-957.

Corrionero A, Minana B, Valcarcel J. 2011. Reduced fidelity of branch point recognition and alternative splicing induced by the anti-tumor drug spliceostatin A. Genes Dev 25: 445-459.

Hoskins AA, Moore MJ. 2012. The spliceosome: A flexible, reversible macromolecular machine. Trends Biochem Sci 37: 179-188.

House AE, Lynch KW. 2006. An exonic splicing silencer represses spliceosome assembly after ATP-dependent exon recognition. Nat Struct Mol Biol 13: 937-944.

Izquierdo JM, Majos N, Bonnal S, Martinez C, Castelo R, Guigo R, Bilbao D, Valcarcel J. 2005. Regulation of Fas alternative splicing by antagonistic effects of TIA-1 and PTB on exon definition. Mol Cell 19: 475-484.

Kafasla P, Mickleburgh I, Llorian M, Coelho M, Gooding C, Cherny D, Joshi A, Kotik-Kogan O, Curry S, Eperon IC, et al. 2012. Defining the roles and interactions of PTB. Biochem Soc Trans 40: 815-820.

Kan JL, Green MR. 1999. Pre-mRNA splicing of IgM exons M1 and M2 is directed by a juxtaposed splicing enhancer and inhibitor. Genes Dev 13: 462-471.

Lin CH, Patton JG. 1995. Regulation of alternative $3^{\prime}$ splice site selection by constitutive splicing factors. RNA 1: 234-245.

Markovtsov V, Nikolic JM, Goldman JA, Turck CW, Chou MY, Black DL. 2000. Cooperative assembly of an hnRNP complex induced by a tissue-specific homolog of polypyrimidine tract binding protein. Mol Cell Biol 20: 7463-7479.

Martinez-Contreras R, Cloutier P, Shkreta L, Fisette JF, Revil T, Chabot B. 2007. hnRNP proteins and splicing control. Adv Exp Med Biol 623: 123-147.

Perez I, Lin CH, McAfee JG, Patton JG. 1997. Mutation of PTB binding sites causes misregulation of alternative $3^{\prime}$ splice site selection in vivo. RNA 3: 764-778.
Sauliere J, Sureau A, Expert-Bezancon A, Marie J. 2006. The polypyrimidine tract binding protein (PTB) represses splicing of exon $6 \mathrm{~B}$ from the $\beta$-tropomyosin pre-mRNA by directly interfering with the binding of the U2AF65 subunit. Mol Cell Biol 26: 8755-8769.

Sharma S, Falick AM, Black DL. 2005. Polypyrimidine tract binding protein blocks the $5^{\prime}$ splice site-dependent assembly of U2AF and the prespliceosomal E complex. Mol Cell 19: 485-496.

Sharma S, Kohlstaedt LA, Damianov A, Rio DC, Black DL. 2008. Polypyrimidine tract binding protein controls the transition from exon definition to an intron defined spliceosome. Nat Struct Mol Biol 15: 183-191.

Sharma S, Maris C, Allain FH, Black DL. 2011. U1 snRNA directly interacts with polypyrimidine tract-binding protein during splicing repression. Mol Cell 41: 579-588.

Shen H, Green MR. 2004. A pathway of sequential arginine-serine rich domain-splicing signal interactions during mammalian spliceosome assembly. Mol Cell 16: 363-373.

Shen H, Kang C. 2001. Two site contact of elongating transcripts to phage T7 RNA polymerase at C-terminal regions. J Biol Chem 276: 4080-4084.

Shen H, Kan JL, Ghigna C, Biamonti G, Green MR. 2004a. A single polypyrimidine tract binding protein (PTB) binding site mediates splicing inhibition at mouse IgM exons M1 and M2. RNA 10: 787-794.

Shen H, Kan JL, Green MR. 2004b. Arginine-serine-rich domains bound at splicing enhancers contact the branch point to promote prespliceosome assembly. Mol Cell 13: 367-376.

Shen H, Zheng X, Shen J, Zhang L, Zhao R, Green MR. 2008. Distinct activities of the DExD/H-box splicing factor hUAP56 facilitate stepwise assembly of the spliceosome. Genes Dev 22: 1796-1803.

Singh R, Valcarcel J, Green MR. 1995. Distinct binding specificities and functions of higher eukaryotic polypyrimidine tract-binding proteins. Science 268: 1173-1176.

Wagner EJ, Garcia-Blanco MA. 2001. Polypyrimidine tract binding protein antagonizes exon definition. Mol Cell Biol 21: 3281-3288.

Watakabe A, Tanaka K, Shimura Y. 1993. The role of exon sequences in splice site selection. Genes Dev 7: 407-418.

Will CL, Luhrmann R. 2011. Spliceosome structure and function. Cold Spring Harb Perspect Biol 3: a003707.

Wu S, Green MR. 1997. Identification of a human protein that recognizes the $3^{\prime}$ splice site during the second step of pre-mRNA splicing. EMBO J 16: 4421-4432.

Wyatt JR, Sontheimer EJ, Steitz JA. 1992. Site-specific cross-linking of mammalian U5 snRNP to the $5^{\prime}$ splice site before the first step of pre-mRNA splicing. Genes Dev 6: 2542-2553. 

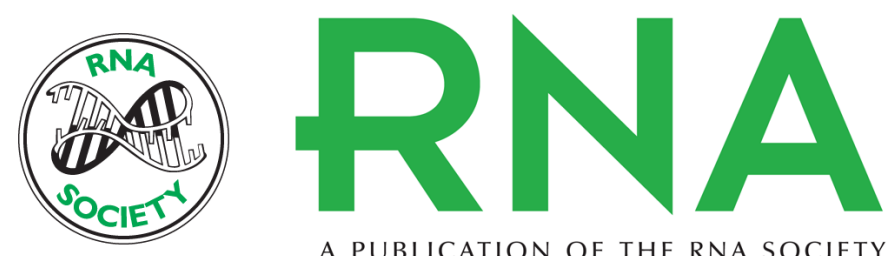

A PUBLICATION OF THE RNA SOCIETY

\section{Polypyrimidine tract binding protein inhibits IgM pre-mRNA splicing by diverting U2 snRNA base-pairing away from the branch point}

Xuexiu Zheng, Sunghee Cho, Heegyum Moon, et al.

RNA 2014 20: 440-446 originally published online February 26, 2014

Access the most recent version at doi:10.1261/rna.043737.113

\section{References This article cites 26 articles, 16 of which can be accessed free at: http://rnajournal.cshlp.org/content/20/4/440.full.html\#ref-list-1 \\ Creative This article is distributed exclusively by the RNA Society for the first 12 months after the Commons full-issue publication date (see http://rnajournal.cshlp.org/site/misc/terms.xhtml). After 12 License months, it is available under a Creative Commons License (Attribution-NonCommercial 3.0 Unported), as described at http://creativecommons.org/licenses/by-nc/3.0/.}

Email Alerting Receive free email alerts when new articles cite this article - sign up in the box at the Service top right corner of the article or click here.

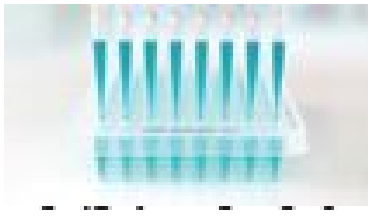

Providing Precise Solutions for your research.

To subscribe to $R N A$ go to:

http://rnajournal.cshlp.org/subscriptions 